International Research Journal of Management, IT \& Social Sciences
Available online at https://sloap.org/journals/index.php/irjmis/
Vol. 6 No. 2, March 2019, pages: 72 78
ISSN: 2395-7492
https://doi.org/10.21744/irjmis.v6n2.610

\title{
The Effect of Tri Hita Karana Culture in Relationship between Work Stress and Internal Auditor Performance
}

\begin{abstract}
CrossMark
A.A. Gde Dwi Aditya ${ }^{a}$

Made Gede Wira Kusuma ${ }^{\text {b }}$

Article history:

Received: 27 September 2018

Accepted: 31 January 2019

Published: 31 March 2019

\section{Keywords:}

auditor;

culture;

performance;

tri hita karana;

work stress;

Abstract

The purpose of this study was to obtain empirical evidence regarding the effect of work stress on auditor performance, and Tri Hita Karana's cultural ability to moderate the effect of work stress on auditor performance. The technique of determining the sample used is the nonprobability sampling method with a purposive sampling technique. The questionnaire is used as a method of data collection. The questionnaire is used as a method of collecting data sent to the internal auditors of Rural Banks (BPR). Of the 51 questionnaires distributed to all BPRs in Badung Regency, 43 questionnaires were feasible to analyze, with a questionnaire return rate of 94 percent and a questionnaire level that could be used at 84 percent. The hypothesis was tested at a 5 percent significance level using the Absolute Difference Value Test. The hypothesis was tested at a significance level of 5 percent using the Absolute Difference Value Test with the SPSS program. The output of the research instrument testing shows that the instrument has passed the validity and reliability test, and has fulfilled the classical assumption test requirements. Of the 51 questionnaires distributed, 43 questionnaires were feasible to be analyzed, with a questionnaire return rate of 94 percent and a questionnaire level that could be used at 84 percent. The results showed that the culture of Tri Hita Karana moderated the effect of work stress on the performance of internal auditors. This means that the culture of Tri Hita Karana is able to weaken the influence of work stress on the performance of internal auditors. The results obtained showed a beta value of -0.521 with a significance value of $p$-value of $0.042(<0.05)$ thus the second hypothesis was accepted. This shows that the cultural perception of Tri Hita Karana owned by an auditor is able to weaken the influence of work stress so that the performance of internal auditors does not decrease.
\end{abstract}

2395-7492@ Copyright 2019. The Author. This is an open-access article under the CC BY-SA license (https://creativecommons.org/licenses/by-sa/4.0/) All rights reserved.

\section{Author correspondence:}

A.A. Gde Dwi Aditya A.,

Faculty of Economic and Business Udayana University, Bali, Indonesia.

Email address: gungdeaditya.as@gmail.com

\footnotetext{
a Faculty of Economic and Business Udayana University, Bali, Indonesia

${ }^{\mathrm{b}}$ Faculty of Economic and Business Udayana University, Bali, Indonesia
} 


\section{Introduction}

Research in the field of behavioral accounting is still widely carried out to date including research on auditor Research in the field of behavioral accounting is still widely carried out to date including research on auditor performance. The research conducted by Masihabadi et al., (2015), entitled Effects of Stress on Auditors' Organizational Commitment, Job Satisfaction, and Job Performance get results where job stress has no effect on auditor performance. Whereas the research conducted by Chen \& Silverthorne (2008), with the research title The Impact of Locus of Control on Job Stress, Job Performance and Job Satisfaction in Taiwan obtained results that job stress has a negative influence on the performance of accountants. The inconsistency of the results of the study is the reason for the researchers to add the Culture of Tri Hita Karana (THK) as a moderating variable in this study. The basic consideration of researchers using traditional culture as a moderating variable is because the people in Bali still maintain a strong traditional culture to this day. Respondents who participated in this study were BPR internal auditors.

There are two things that form the basis of consideration for choosing an RB internal auditor as a respondent. First, considering that each BPR is required to appoint executive officers responsible for the conduct of internal audits, so it can be said that each BPR has an internal auditor. Second, the business scope of BPR in Bali is more focused in the Bali region, unlike commercial banks that have business scope in various regions, so that BPR workers are dominated by Balinese who are mostly Hindus, considering that one of the variables used in this study is closely related to culture. Balinese Hinduism namely THK.

The concept of THK is the concept of harmonizing relationships that are always guarded by the Balinese Hindu community including parahyangan (human relations with God), pawongan (human relations), and palemahan (human relations with the environment). Budiadnyani (2017), states that the harmonization of relations that occur between humans and God, between humans, and humans and the environment are expected to reduce the pressure faced by auditors. The reduced pressure faced by auditors will have implications for increasing auditor performance so that auditors are able to achieve a better level of performance and be able to produce high-quality audits.

\section{Literature Review}

\subsection{Internal audit}

According to The Institute of Internal Auditors, internal auditing is objective assurance and consulting activities designed to provide added value and improve organizational operations. This helps organizations achieve their goals by bringing a systematic and disciplined approach to evaluating and improving the effectiveness of the risk management, control, and governance processes. Internal audits are carried out by professionals with an in-depth understanding of business culture, systems and processes, internal audit activities provide assurance that internal control is sufficient to mitigate risk, the governance process runs effectively and efficiently, and the goals and objectives of the organization are appropriate.

\subsection{Rural Bank Internal Audit (BPR)}

BPR operates its operations by collecting and channeling funds from the community so that BPRs have a large responsibility for the community. Therefore the Financial Services Authority (OJK) as a regulator requires each BPR to appoint an internal audit executive or work unit. As stipulated in the Financial Authority Circular Number 7 / SEOJK.03 / 2016 article 59, each BPR is required to appoint executive officers responsible for the implementation of the internal audit function that is independent of operational functions.

\subsection{Work Stress}

May (2009), mentions that many stress studies have been carried out where stress was initially considered as a form of an organism's response to external stimuli. May (2009), added that after several decades of research, it was discovered that stress is a far more complex problem than just a physical response. Larson (1997), states that certain stress levels are considered important for individuals to do good work. However, uncontrolled organizational stress can produce individual stress and tensions that are detrimental to both individuals and organizations (Larson, 1997). According to Dewe (1992) in May (2009), stress is related to physical and mental health, and one's adaptation to the environment. Environmental changes that occur require proper adaptation. A person can feel depressed if they are

Aditya, A. G. D., \& Kusuma, M. G. W. (2019). The effect of tri hita karana culture in relationship between work stress and internal auditor performance. International Research Journal of Management, IT and Social Sciences, 6(2), 72-78. https://doi.org/10.21744/irjmis.v6n2.610 
unable to adapt to changes that are major events in his life. A person may also feel stressed when they have too many daily disorders to deal with, or when they feel the stress of the deadline in completing their tasks.

\subsection{Hypothesis}

The Effect of Work Stress on Auditor Performance with Tri Hita Karana Culture as Moderating

Unlike the previous findings, the research conducted by Masihabadi et al., (2015), regarding the influence of Stress on Organizational Commitment, Job Satisfaction, and Auditor Performance in Tehran obtained results that work stress has no effect on auditor performance. The inconsistent research results were considered by the researchers to add the Tri Hita Karana Cultural variable as a moderating variable. Tri Hita Karana emphasizes the equilibrium theory that Hindu society tends to view themselves and their environment as a system that is controlled by equilibrium values and manifested in the form of behavior (Gunawan, 2009). The existence of the culture of Tri Hita Karana will later create harmony in the giving of orders so that the command does not cause stress on subordinates. Based on the description above, the hypothesis is proposed as follows:

Ha: Tri Hita Karana culture weakens the effect of work stress on auditor performance

\section{Materials and Methods}

Respondents selected in this study were determined by purposive sampling method. Based on the hypothesis formulated in this study, there are three types of variables, namely the independent variable, the dependent variable, and the moderating variable. The independent variable used in this study is work stress, while the one used as the dependent variable is performance and the moderating variable used is traditional culture. The analysis technique used for hypothesis testing is the Absolute Difference Value Test with the help of the SPSS computer program (Statistical Product and Service Solutions). The results of the analysis obtained are interpreted to answer the research problem. Furthermore, a conclusion is made from the research carried out accompanied by limitations and suggestions.

\section{Results and Discussions}

The hypothesis in this study was tested using multiple linear regression equations using the Absolute Difference Value Test method. The regression equation in this study are as follows:

$$
\begin{aligned}
\mathrm{Y} & =\alpha+\beta_{1} \mathrm{TK}+\beta_{2} \mathrm{THK}+\beta_{3}\left[\left(\mathrm{TK}^{*} \mathrm{THK}\right)\right]+\mathrm{e} \\
& =21,515-0,308 \mathrm{TK}+0,478 \mathrm{THK}-0,521 \mathrm{TK} \times \mathrm{THK}
\end{aligned}
$$

Based on the regression equation above, if the regression coefficient value of work stress and tri hita karana is zero then the coefficient value of internal auditor performance is 21,515 . The regression equation also shows a negative effect of the interaction between work stress and tri hita karana (TK x THK) on the performance of internal auditors.

Table 1

Result

\begin{tabular}{lccc}
\hline & Variable & Unstandardized coefficients & Sig \\
\hline (constant) & B & 60,755 & 0,000 \\
Job Stress & 21,515 & $-1,307$ & 0,199 \\
Tri Hita Karana & $-0,308$ & 2,022 & 0,050 \\
(JS X THK) & 0,478 & $-2,100$ & 0,042 \\
\hline
\end{tabular}

Primary Data, 2018 


\subsection{Coefficient of Determination}

The results of the analysis show that the $\mathrm{R} 2$ value is 0.221 . This shows that 22.1 percent of the variation in the variable changes in the performance of internal auditors can be explained by the variable work stress, tri hita karana, and the interaction between work stress and tri hita karana, while the remaining 77.9 percent is explained by other factors that are not explained in the model.

\subsection{Model Feasibility Test Results (Test F)}

The $\mathrm{F}$ test is used to test whether the independent variables used in this study simultaneously have an influence on the dependent variable and can also be used as an assessment that the research model tested is a feasible research model. Based on the results of data processing carried out by the computer program Statistical Package for Social Science (SPSS) obtained F significance value of $0.02<0.05$. This shows that each independent variable jointly influences the dependent variable. These results also show that the model used in this study is fit.

\section{The Effect of Tri Hita Karana on the relationship between Work Stress and Internal Auditor Performance}

The test results with the absolute value difference test show that Tri Hita Karana is able to moderate the effect of work stress on the performance of internal auditors. The test results also obtain a negative beta value which means that tri hita karana weakens the effect of work stress on the performance of internal auditors. Gunawan (2011), mentions the philosophy of Tri Hita Karana stating that Hindu communities tend to view themselves and their environment as a system controlled by balance values, and manifested in the form of behavior: (1) always want to adapt themselves to their environment, resulting in the impression that Balinese are strong pattern, but easy to accept adaptation; (2) always wants to create peace within him and balance with his environment. According to Adiputra (2014), a strong grip on tri hita karana values for each internal auditor can provide support for their mindset to always carry out their duties as a process that themselves as individuals who continue to learn and motivate themselves in gaining knowledge and experience in implementing audit assignment.

The results of this study are supported by Budiadnyani (2017), who obtained results that tri hita karana weakened the effect of role conflict and excess role on auditor performance. Budiadnyani (2017), states that tri hita karana gives birth to values which include the principles of parahyangan, pawongan and palemahan giving birth to values that consist of: piety, honesty, creativity, hard work without knowing despair, respecting time, harmonious cooperation, satya discourse, ethical efficiency, full of initiative and enthusiasm to build, maintain, and secure.

High work stress causes the performance of internal auditors to decline, but by holding on to the values of tri hita karana raises the balance and harmony in an auditor so that the stress experienced does not reduce its performance. Praying before work (parahyangan) will provide a sense of calm in an auditor so that he can carry out his duties better. Maintaining a working environment (palemahan) to keep it clean and tidy can provide an auditor with a sense of comfort when working so that he can carry out his duties more carefully. Maintaining a good relationship with coworkers (pawongan) can make the audit process run more smoothly because the audited employees are cooperative with the internal auditor.

\section{Conclusion}

Tri hita karana weakens the effect of work pressure on auditor performance. This shows that high work pressure can cause a decrease in performance, especially for internal auditors who do not hold on to the values of tri hita karana. Conversely, the higher the belief in tri hita karana values will cause the influence of the work pressure faced by an internal auditor in carrying out his duties decreases and does not interfere with his performance.

\section{Suggestion}

Based on the results of this study, some suggestions that can be conveyed are that this study has several limitations, one of which is the instrument in this study using only a questionnaire. Further research is recommended

Aditya, A. G. D., \& Kusuma, M. G. W. (2019). The effect of tri hita karana culture in relationship between work stress and internal auditor performance. International Research Journal of Management, IT and Social Sciences, 6(2), 72-78. https://doi.org/10.21744/irjmis.v6n2.610 
to also conduct interviews directly with respondents so that researchers can provide more open-ended questions related to the development of research.

Further research is recommended to add research variables. One of the variables that can be used is work-family life conflict. One of the most important values in human life is that family life can conflict with life in the world of work needed for continuity and quality of life. High levels of activity in work can be a barrier to fulfilling household obligations. Vice versa, problems that occur in fulfilling household obligations can disrupt work.

The results showed that the culture of Tri Hita Karana was able to reduce the influence of work pressure on the performance of internal auditors. The cultural value of Tri Hita Karana is able to harmonize the pressure faced by the auditor so that the auditor's performance remains good. It is recommended to consider the cultural aspects of Tri Hita Karana into organizational culture, for example by making a policy so that employees apply the values of Tri Hita Karana in work such as praying before work, maintaining good relations with colleagues, and keeping the work environment clean and tidy maintain harmony and harmony in the work environment of the company.

Conflict of interest statement and funding sources

The authors declared that they have no competing interest. The study was financed by personal funding.

Statement of authorship

The authors have a responsibility for the conception and design of the study. The authors have approved the final article.

\section{Acknowledgments}

The authors would like to thank the editor of IRJMIS for their valuable time, support and advice. 


\section{References}

Adiputra, I. M. P., Atmadja, A. T., \& Saputra, K. A. K. (2014). Budaya Tri Hita Karana Sebagai Pemoderasi Pengaruh Locus Of Control Dan Kompleksitas Tugas Terhadap Kinerja Internal Auditor (Studi Pada 5 Kantor Inspektorat Di Provinsi Bali).

Budiadnyani. (2017). "Kemampuan Budaya Tri Hita Karana Memoderasi Pengaruh Elemen Role Stress Pada Kinerja Auditor". (tesis) Program Pascasarjana Universitas Udayana.

Chen, J. C., \& Silverthorne, C. (2008). The impact of locus of control on job stress, job performance and job satisfaction in Taiwan. Leadership \& Organization Development Journal, 29(7), 572-582. https://doi.org/10.1108/01437730810906326

Chen, J. C., Silverthorne, C., \& Hung, J. Y. (2006). Organization communication, job stress, organizational commitment, and job performance of accounting professionals in Taiwan and America. Leadership \& organization Development journal, 27(4), 242-249. https://doi.org/10.1108/01437730610666000

Dewi, N. K. J., \& Wirakusuma, M. G. Prediktor kinerja internal auditor pada pt astra motor provinsi Bali. E-Jurnal Akuntansi, 2099-2121.

Du, M. (2009). The effects of leisure time physical activity, coping strategies, job stress and job satisfaction on perceived wellness: A study with managerial staff in sport and recreation in Hong Kong.

Gunawan, K. (2011). Peran Falsafah Tri Hita Karana Bagi Pertumbuhan dan Kinerja Lembaga Perkreditan Desa (LPD) di Bali. Jurnal Analisis Manajemen, 5(2), 23-36.

Larson, L. L. (1997). Internal auditor job stress and turnover intentions (Doctoral dissertation, Cleveland State University).

Lee Larson, L. (2004). Internal auditors and job stress. Managerial Auditing Journal, 19(9), 1119-1130. https://doi.org/10.1108/02686900410562768

Masihabadi, A., Rajaei, A., Shams Koloukhi, A., \& Parsian, D. (2015). Effects of stress on auditors' organizational commitment, job satisfaction, and job performance. International Journal of Organizational Leadership, 4, 303314.

Aditya, A. G. D., \& Kusuma, M. G. W. (2019). The effect of tri hita karana culture in relationship between work stress and internal auditor performance. International Research Journal of Management, IT and Social Sciences, 6(2), 72-78. https://doi.org/10.21744/irjmis.v6n2.610 


\section{Biography of Author}

\begin{tabular}{|l|l||}
\hline AA. Gede Dwi Aditya was born in Denpasar. Finished his Master Program at Udayana \\
University. He is interested in Accounting. Currently as an auditor in Public Accountant \\
Firm in Denpasar. \\
Email: gungdeaditya.as@gmail.com
\end{tabular}

